\title{
Update on human exposure to glyphosate, with a complete review of exposure in children
}

\author{
Christina Gillezeau, Wil Lieberman-Cribbin and Emanuela Taioli* (i)
}

\begin{abstract}
Background: Glyphosate, a commonly used pesticide, has been the topic of much debate. The effects of exposure to glyphosate remains a contentious topic. This paper provides an update to the existing literature regarding levels of glyphosate exposure in occupationally exposed individuals and focuses or reviewing all the available published literature regarding glyphosate exposure levels in children.

Methods: A literature review was conducted and any articles reporting quantifiable exposure levels in humans published since January 2019 (the last published review on glyphosate exposure) were reviewed and data extracted and standardized.

Results: A total of five new studies reporting exposure levels in humans were found including 578 subjects. Two of these studies focused on occupationally exposed individuals while three of them focused on glyphosate exposure levels in children. Given the sparse nature of the new data, previously identified studies on exposure to glyphosate in children were included in our analysis of children's exposure. The lowest average level of glyphosate exposure reported was $0.28 \mu \mathrm{g} / \mathrm{L}$ and the highest average exposure levels reported was $4.04 \mathrm{\mu g} / \mathrm{L}$.

Conclusion: The literature on glyphosate exposure levels, especially in children, remains limited. Without more data collected in a standardized way, parsing out the potential relationship between glyphosate exposure and disease will not be possible.
\end{abstract}

Keywords: Review, Round up, Youth, Glyphosate exposure, AMPA, Urinary biomarkers

\section{Introduction}

The concerns associated with exposure to glyphosate, the active ingredient in the pesticide Round Up, have been a topic of much debate due to recent rulings and legal cases in the United States against the company that manufactures Round Up, Monsanto, which have concluded that the chemical may be carcinogenic [1]. Despite its widespread use worldwide and because of the introduction of genetically modified seeds that are

\footnotetext{
* Correspondence: Emanuela.Taioli@mountsinai.org

The Institute for Translational Epidemiology at the Icahn School of Medicine at Mount Sinai, One Gustave L Levy Place, Box 1133, New York, NY 10029, USA
}

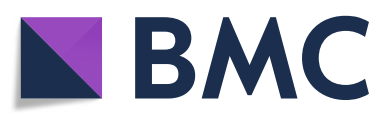

(C) The Author(s). 2020 Open Access This article is licensed under a Creative Commons Attribution 4.0 International License, which permits use, sharing, adaptation, distribution and reproduction in any medium or format, as long as you give appropriate credit to the original author(s) and the source, provide a link to the Creative Commons licence, and indicate if changes were made. The images or other third party material in this article are included in the article's Creative Commons licence, unless indicated otherwise in a credit line to the material. If material is not included in the article's Creative Commons licence and your intended use is not permitted by statutory regulation or exceeds the permitted use, you will need to obtain permission directly from the copyright holder. To view a copy of this licence, visit http://creativecommons.org/licenses/by/4.0/ The Creative Commons Public Domain Dedication waiver (http://creativecommons.org/publicdomain/zero/1.0/) applies to the data made available in this article, unless otherwise stated in a credit line to the data.
Round-Up resistant, and its adoption in the early 2000s as a mean to speed up crop desiccation [2], the amount of exposure in the general population and the potential effects of sustained exposure on human health are largely unknown. The amount of permissible residues of glyphosate on crops has increased correspondingly [3], despite the fact that the literature on the health effects is scarce. A recent meta-analysis has suggested that glyphosate use in an occupational setting may raise the risk of non-Hodgkin lymphoma as much as $41 \%$ [4]; a pooled analysis of case-control studies from North America confirmed the association, and suggested that specific histologic subtypes of non-Hodgkin lymphoma may be 
associated with exposure to glyphosate [5]. As with any chemical, there are multiple steps involved in evaluating risk, which include gathering information about human exposures, so that the levels that produce harm in one population or animal species can be compared to typical exposure levels. However, we have previously shown that data on human exposure in workers and the general population are very limited [6]. Several other gaps in knowledge exist around this product, for example results on its genotoxicity in humans are limited. The continued debate regarding the effects of glyphosate exposure makes establishing exposure levels in the general public a pressing public health issue, especially for the most vulnerable. As such, we have endeavored to summarize what is known about exposure levels of glyphosate and its metabolite, Aminomethylphosphonic acid (AMPA). Research shows that children are especially vulnerable to environmental toxins in general due to their small body mass; in the case of glyphosate, they are also more likely to be exposed due to contact with dirt in playgrounds [7]. As a result, children and occupationally exposed adults are the individuals most likely to experience harm from glyphosate exposure. We are now presenting an updated review of the literature on exposure to glyphosate, with a focus on children's exposure.

\section{Methods}

We conducted a PubMed and Google Scholar search using the following terms: "glyphosate" ("glyphosate" OR "1071-83-6" OR "roundup" OR "N-(Phosphonomethyl)glycine") or ((("AMPA") NOT "AMPA receptor")) OR "Aminomethylphosphonic acid") AND ("human") from November 12,018, the date of our last literature review, to March 312,020. No limitation on language of the publication was imposed on the search. The search returned 181 results. After title and abstract review, 147 studies were excluded because they did not report information on exposure levels in human subjects. After a full article review, a further 29 studies were excluded because they did not report a quantifiable level of exposure for their participants. Five studies were ultimately included in this updated review, which included two studies that focused on urinary glyphosate levels in children and three studies that focused on urinary glyphosate levels in occupationally exposed adults. Because of the very limited data available regarding exposure levels in children, data from two previously identified studies were also included in order to report a complete, updated analysis on exposure in children $[8,9]$.

Average glyphosate levels were abstracted and standardized to $\mu \mathrm{g} / \mathrm{L}$. For the three studies where the geometric mean (GM) was not reported, the GM was estimated [10] from the arithmetic mean (AM) using the formula $G M=\frac{A M^{2}}{\sqrt{A M^{2}+S D_{y}^{2}}}$, where $\mathrm{SD}_{\mathrm{x}}$ is the standard deviation of the data on the native scale and AM is the arithmetic mean of the data on the native scale. For the two studies where the range was not reported, it was estimated to be $3 \mathrm{SD}_{\mathrm{y}}$, as this would account for $99.7 \%$ of the values.

\section{Results}

There were five new studies published in the past 2 years and included in this update, two of which measured urinary glyphosate levels in children [11, 12], and three [13-15] measured urinary glyphosate levels in agricultural workers. One of those three studies also provided urinary glyphosate levels in non-agricultural workers as a comparison group [15]. A total of 578 new individuals were included among all of the studies with 389 children, 38 adults in the general population and 151 adult agricultural workers. The lowest LOD for glyphosate reported was $0.01 \mu \mathrm{g} / \mathrm{L}$ [12] and the highest was $5 \mu \mathrm{g} / \mathrm{L}$ [14]. The lowest average level of urinary glyphosate within the detectable results reported was $0.28 \mu \mathrm{g} / \mathrm{L}$ [10] and the highest was $4.04 \mu \mathrm{g} / \mathrm{L}$ [13]. Only two of the studies reported AMPA levels in the included subjects $[13,14]$ (Table 1).

\section{Studies on children}

In a study from the United States, urinary glyphosate levels were measured using HPLC-MS/MS (LOD $0.1 \mu \mathrm{g} / \mathrm{L}$ and LOQ $0.33 \mu \mathrm{g} / \mathrm{L}$ ) in urine samples from children in three different age ranges. Ten newborns (less than 30 days old), 66 infants (10-19 months of age), and 32 children (ages 3 to 8 years), provided urine samples to measure glyphosate exposure levels in New York, NY and Seattle, WA within the United States. The AM \pm SD glyphosate level was calculated including all 108 children with values below the LOD imputed as $\frac{L O D}{\sqrt{2}}$ and was equal to $0.28 \pm 0.29 \mu \mathrm{g} / \mathrm{L}$; the range of detectable values was $0.105-2.125 \mu \mathrm{g} / \mathrm{L}$. The mean $\pm \mathrm{SD}$ levels were not reported by age group, although the median urinary glyphosate levels were below the LOD in each age group [11].

Urinary levels of glyphosate were measured using HPLC-MS/MS (LOD: 0.01-1000 $\mu \mathrm{g} / \mathrm{L}$ ) in 192 children < 17 years living in Agua Caliente and 89 children $<12$ years living in Ahuacapán, two rural areas in Mexico; $72.91 \%$ of the children in Agua Caliente had detectable levels of glyphosate (AM \pm SD: $0.363 \pm 0.321 \mu \mathrm{g} / \mathrm{L}$ ), versus $100 \%$ in Ahuacapán $(\mathrm{AM} \pm \mathrm{SD}: 0.606 \pm 0.5435 \mu \mathrm{g} / \mathrm{L})$ [12].

We previously identified two studies that reported glyphosate levels in children, one of which was conducted in the US, while the other was conducted in Denmark. The first study was conducted in Iowa in 2007; urinary glyphosate levels were measured in 182 samples from 51 


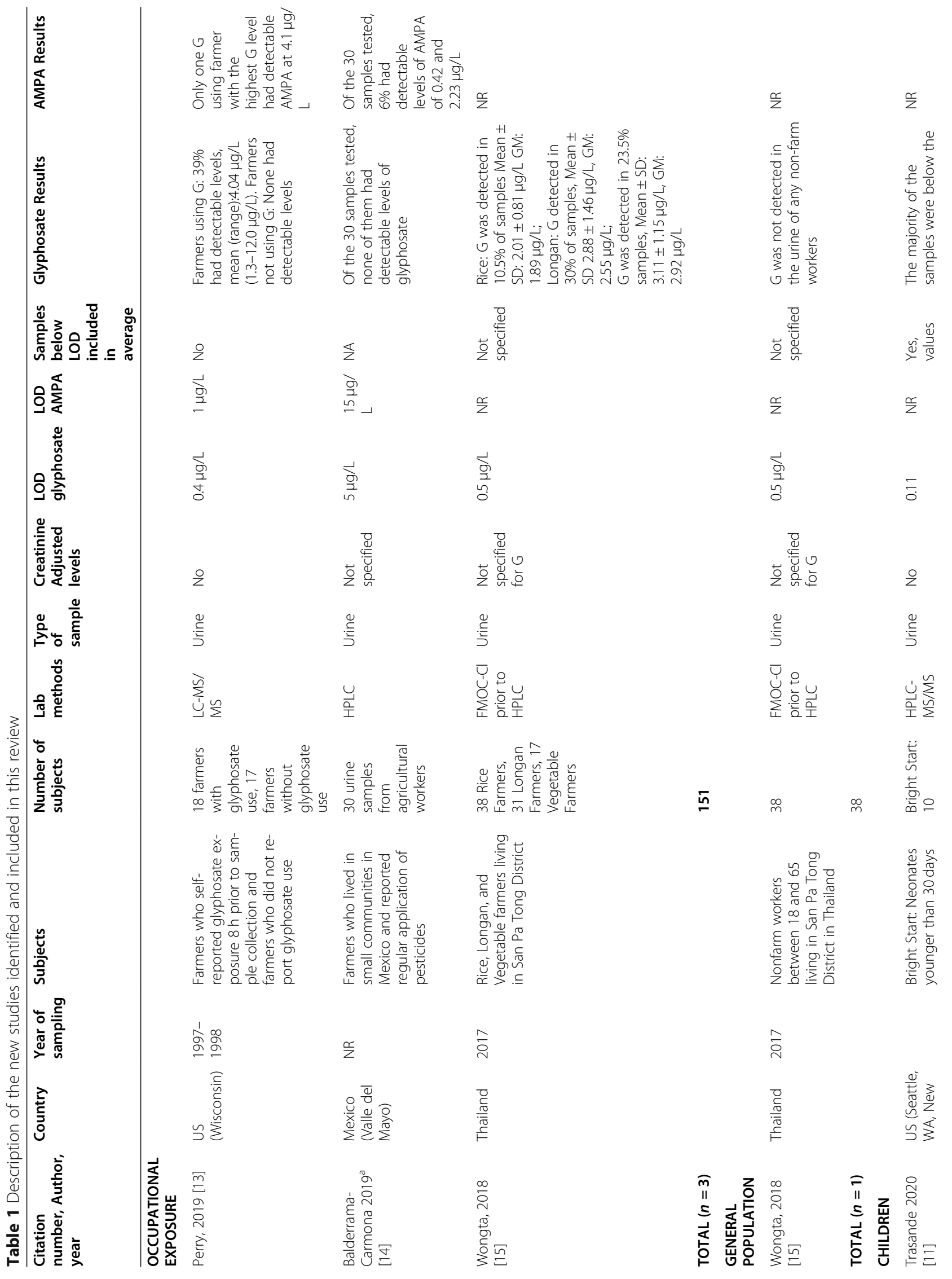




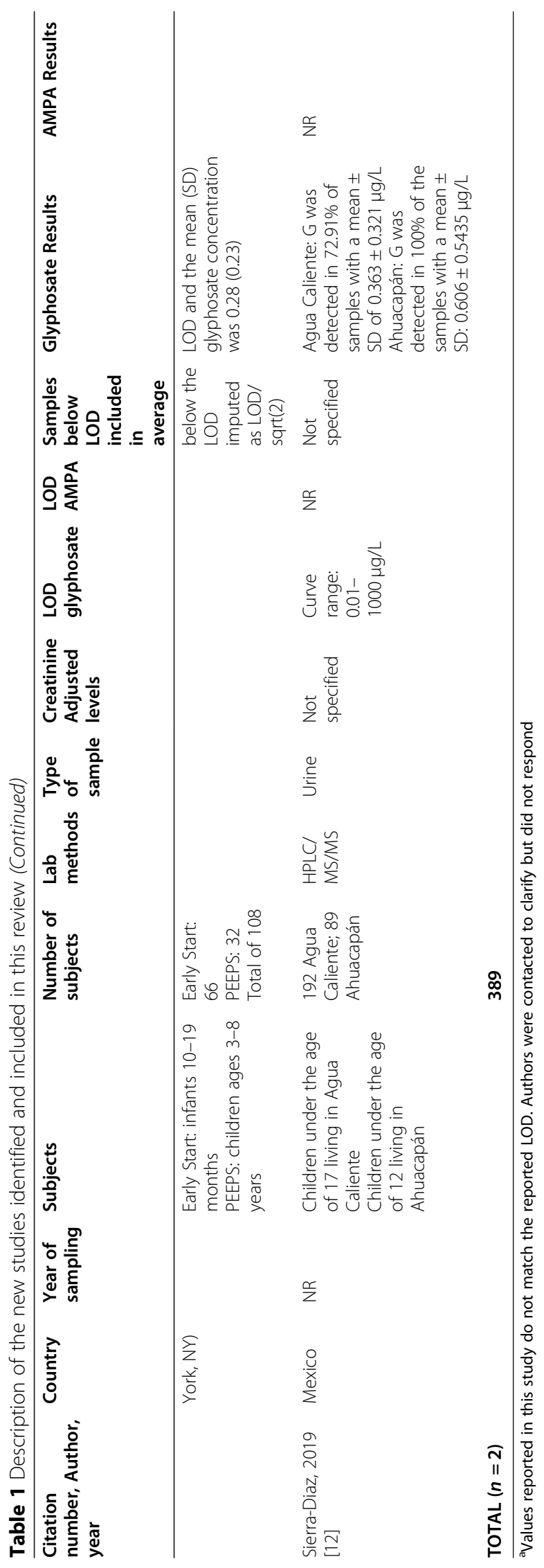


children from non-farming households and in 235 samples from 66 children from farming households, using a fluorescent covalent microbead immunoassay (LOD: $0.09 \mu \mathrm{g} / \mathrm{L}$ ). Values below the LOD were included as 0 , and all values were log-transformed prior to modeling. Excluding the 66 samples (22 from non-farming households and 44 from farming households) with levels reported as non-detected or below the LOD, the range of glyphosate levels was $0.10-9.4 \mu \mathrm{g} / \mathrm{L}$ for non-farming children and $0.022-18 \mu \mathrm{g} / \mathrm{L}$ for farming children. Glyphosate values were above the LOD in $88 \%$ of the children from non-farming, and $81 \%$ of the children from farming households (adjusted geometric means: 2.5 (95\% CI: $2.1-3.1) \mu \mathrm{g} / \mathrm{L}$ and 1.9 (95\% CI: $1.3-2.5) \mu \mathrm{g} / \mathrm{L}$ respectively). Values in children were higher than levels of their parents, regardless of whether the parents worked on a farm or not [8].

In the Danish study, urinary glyphosate levels of 14 children aged 6 to 11 years from both urban and rural communities were measured with ELISA (LOD: $2.5 \mu \mathrm{g} /$ L). The AM level of glyphosate was 1.96 (range: 0.853.31) $\mu \mathrm{g} / \mathrm{L}$, and all of the samples had a detectable level, without significant differences between children from urban vs rural homes [9]. Because of the differing methods of analysis, no attempt at meta-analysis was completed on the studies that included children, but the average glyphosate levels reported in children ranged from $0.28 \mu \mathrm{g} / \mathrm{L}$ [6] to $2.5 \mu \mathrm{g} / \mathrm{L}$ [9] (Fig. 1).

\section{Occupationally exposed individuals}

In Perry 2019, urine samples were collected from 18 farmers who reported using glyphosate and 200 farmers who did not; samples were cryopreserved after being collected between 1997 and 1998 [13]. The urine samples from the 18 glyphosate users and 18 randomly selected samples from the pool of 200 glyphosate non-users were analyzed using high performance liquid chromatography tandem mass spectrometry (HPLC-MS/MS). The LOD for glyphosate was $0.4 \mu \mathrm{g} / \mathrm{L}$ and was $1 \mu \mathrm{g} / \mathrm{L}$ for aminomethylphosphonic acid (AMPA). One of the 18 glyphosate non-user samples could not be analyzed. Of the remaining 17 samples, none had glyphosate levels above the LOD.. In the 18 glyphosate user samples, seven of the 18 samples had detectable levels of glyphosate with a range of $1.3-12.0 \mu \mathrm{g} / \mathrm{L}$ and an $\mathrm{AM}$ of $4.04 \mu \mathrm{g} / \mathrm{L}$. Only the sample with the highest level of glyphosate, $12 \mu \mathrm{g} / \mathrm{L}$, had a detectable level of AMPA.

In a 2019 study by Balderrama-Carmona et al. from Valle del Mayo, Sonora Mexico, urine samples from 30 agricultural workers who applied herbicides were analyzed for glyphosate and AMPA using high-pressure liquid chromatography to calculate calibration curves using blanks and different concentrations of aqueous patterns of glyphosate and AMPA [14]. The correlation coefficient for the calibration curve for both AMPA and glyphosate was $\mathrm{R}^{2}=0.994$. The LOD for $5 \mu \mathrm{g} / \mathrm{L}$ for glyphosate and $15 \mu \mathrm{g} / \mathrm{L}$ for AMPA. In testing, $6 \%$ of samples had detectable levels of AMPA and none of the samples had detectable levels of glyphosate. The AMPA concentrations reported for the two urine samples that contained detectable levels of AMPA were 0.42 and $2.23 \mu \mathrm{g} / \mathrm{L}$. Because of the discrepancy between the LOD and the actual urinary values reported, the study was considered of low quality.

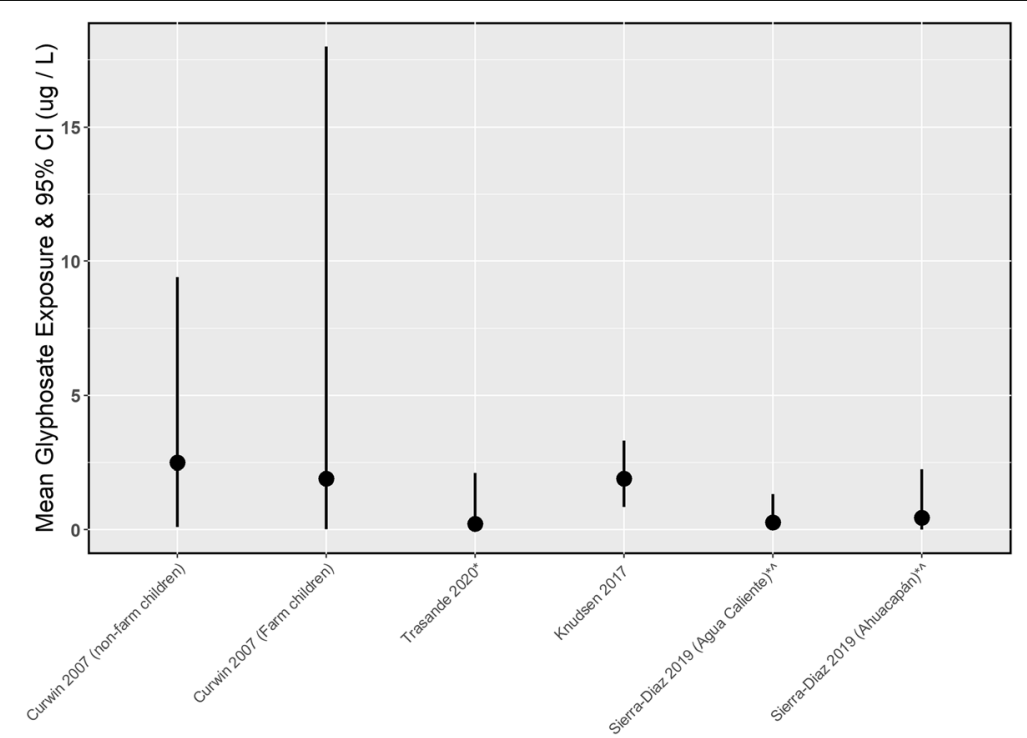

Fig. 1 Urinary Geometric Mean Glyphosate Concentrations in Children. *GM was estimated from AM and SD; ${ }^{\wedge}$ Range was estimated from SD; $\sim$ SD was estimated from range and AM 
In a 2018 Thai study glyphosate levels in urine samples from 38 rice farmers, 31 longan farmers, and 17 vegetable farmers were measured using fluorenylmethyloxycarbonyl chloride prior to HPLC, which had an $80 \%$ recovery, an interbatch residual standard deviation of $3.0 \%$ and an intrabatch residual standard deviation of $8.9 \%$ [15]. The LOD was $0.5 \mu \mathrm{g} / \mathrm{L}$. Ten percent of the rice farmers, $30 \%$ of the longan farmers, and $23 \%$ of the vegetable farmers had detectable levels of glyphosate. Among the rice farmers with detectable levels of glyphosate, the $\mathrm{AM} \pm \mathrm{SD}$ glyphosate level was $2.01 \pm 0.8 \mu \mathrm{g} / \mathrm{L}$, among longan farmers was $2.88 \pm 1.46 \mu \mathrm{g} / \mathrm{L}$ and among vegetable farmers was $3.11 \pm 1.15 \mu \mathrm{g} / \mathrm{L}$ (Fig. 2).

\section{Discussion}

The literature review shows that the amount of work published on glyphosate levels in the population continues to be very limited. In the last 2 years, only five new studies reporting actual values of glyphosate in humans were published, and even when combined with the studies in our previous review, only 4299 individuals have been tested worldwide $[6,8,9,11-15]$ for their urinary glyphosate level and only 520 of them are children $[8,9,11,12]$. Only two of the new studies were conducted in the United States $[11,13]$, bringing the total number of studies conducted in the US to six. Another remarkable aspect of this review is the paucity of measurements of AMPA together with glyphosate. Measuring residues and metabolites allow to better understand the individual ability to degrade the main compound, as well as to detect other by-products, such as AMPA, which carries its own safety concerns [16]. Additionally, since glyphosate is non-persistent with an

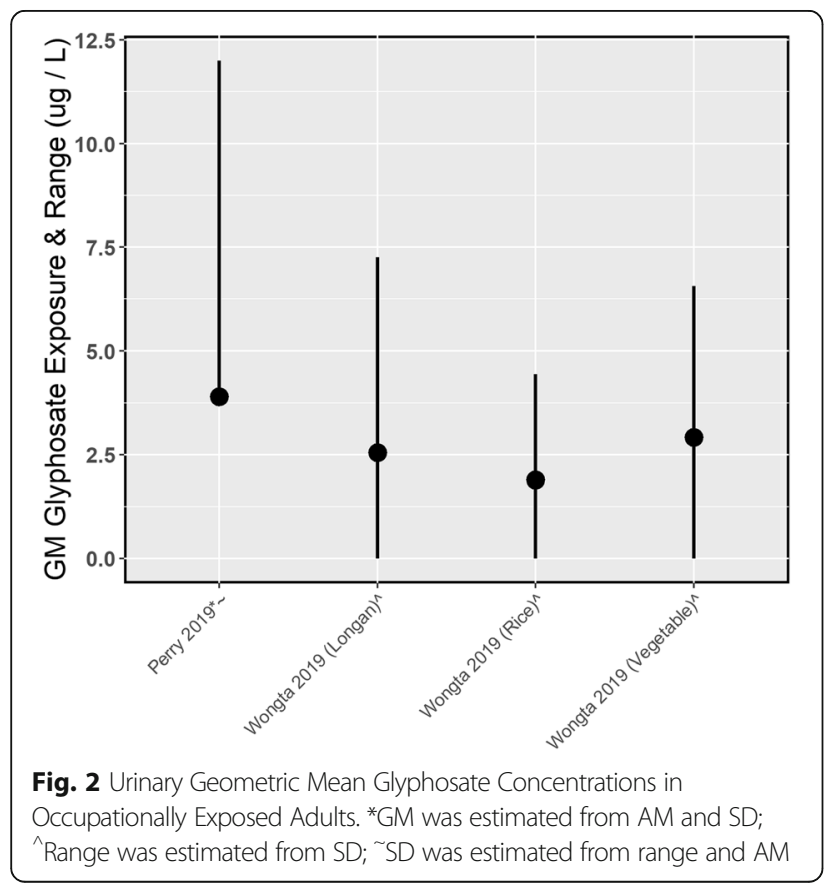

estimated biological half-life in urine ranging between five and a half and $10 \mathrm{~h}$ depending on the measurement and adjustment methods [17], measurement of AMPA levels within these samples is essential for accurate estimation of true exposure levels.

In terms of laboratory methods, fluorescent covalent microbead immunoassay [8], ELISA [9], HPLC [14], LCMS/MS [13], HPLC-MS/MS [11, 12], and 9fluorenylmethyloxycarbonyl chloride to derivatize urine samples prior to using high pressure liquid chromatography were deployed [15]. Although there is not a definitive best practice for measurement of glyphosate levels. Research with other non-persistent chemicals with short half-lives like bisphenol A has found that ELISA lacks the necessary sensitivity and specificity to accurately measure exposure [18]. MS provides a low LOD and is routinely used by the CDC's Environmental Health Laboratory [19], suggesting it is likely a more robust measurement method.

When reviewing the published literature, we endeavored to find statistical methods for measuring the accuracy or at least consistency of the results reported. Most of the studies, however, did not report repeated measures that would allow for calculation of coefficient of variation or comparison across methods. Researchers might consider reporting the coefficient of variation or intra-correlation coefficient within the results to allow for better comparison between studies.

Of interest, there are now six data sets from four distinct studies reporting on children. All the studies confirm the presence of glyphosate in urine samples from children, both within and outside of agricultural communities, with values exceeding those measured in adults when the corresponding values were available. Previous research suggests multifactorial reasons for higher levels of environmental toxin exposure in children, which may include smaller body mass or higher likelihood of ingestion, particularly in younger children who are inclined to put non-food items in their mouths. Children may also be exposed through their play on the ground and in the dirt, particularly dirt from playgrounds, which may be contaminated by toxins deposited in the soil or dust. This may be particularly true in households where parents are occupationally exposed to toxins and may bring those toxins home inadvertently on their clothing, thereby increasing their child's exposure. Additionally, even if children's exposure levels are not higher than adults, their growth and maturation may be impacted by toxins in a way that adults' will not be. Furthermore, they may be more likely to develop disease from exposure given the increased number of years for chronic exposure a child might have as compared to someone exposed in adulthood [7]. Given the evidence that children are especially vulnerable to environmental carcinogens $[20,21]$, tracking exposure to products such 
as glyphosate in children is a pressing public health priority. The lack of data on glyphosate exposure in children, and on time trends, geographic variability, and sources of exposure call for systematic monitoring of glyphosate and for more studies on the biological effects of the exposure in the general population as well as in vulnerable subsets.

The levels of glyphosate exposure in occupationally exposed individuals is also a major concern. Although the highest average urinary level of glyphosate reported in these updated studies (AM [range]: 4.0 [1.3-12.0] $\mu \mathrm{g} / \mathrm{L}$ ) [13] did not reach the highest level seen in previous studies we reviewed, (AM [range]: $73.6[40.2->80.0] \mu \mathrm{g} / \mathrm{L}$ ) [22], the average urinary glyphosate level in occupationally exposed individuals is still disconcertingly high. The decrease in average levels may reflect better personal protective equipment usage, in light of the increased publicity surrounding the potential hazards of glyphosate exposure. However, given the results of a 2017 study showing glyphosate and AMPA levels increasing over time in non-farmer US and European adults [23], it the current result is likely a reflection of a smaller number of studies, only one of which was conducted in the US, published in the last few years compared to the last review we published.

In terms of methodological aspects, of the three studies that measured occupational exposure, two collected convenience samples from farmers, rather than collecting samples at set intervals before and after exposure. None of the studies collected information on urinary glyphosate levels prior to occupational use. This, combined with the lack of data on glyphosate levels in the non-occupationally exposed general population, makes parsing out the various sources of the observed glyphosate levels in the occupationally exposed difficult, as such levels can also derive from food, drinking water, wind or dust in addition to occupational exposure [24-26]. We suggest that studies measuring glyphosate levels in occupationally exposed individuals should attempt to collect samples prior to application, the day of application, and in the days after application, as well as gathering information about how regularly farmers apply glyphosate. This will provide sufficient information to distinguish a baseline level of exposure from the effect of recent application. Regardless, without more standardized measurement practices, it remains difficult to establish just how much more exposure occupationally exposed individuals have compared to the average adult.

Monitoring of urinary glyphosate levels should be conducted in the general population, but is especially important for those who are occupationally exposed and those vulnerable. We continue to suggest that inclusion of glyphosate as a measured exposure in nationally representative studies like the National Health and Nutrition Examination Survey will allow for a better understanding of the risks that glyphosate may pose and allow for better monitoring of those who are most likely to be exposed and those who are more susceptible to the exposure.

\section{Abbreviations \\ LOD: Limit of Detection; ELISA: enzyme-linked immunosorbent assay; PPB: Parts per billion; HPLC: High-Performance Liquid Chromatography; MS/ MS: Tandem Mass Spectrometry; AMPA: Aminomethylphosphonic Acid}

\section{Acknowledgements}

Not applicable.

\section{Authors' contributions}

CG and WLC completed the literature review and drafted the manuscript. ET conceived of the project and edited the manuscript with CG and WLC.

Funding

The authors received no funding for this work.

\section{Availability of data and materials}

This is a review and all data is publicly available.

Ethics approval and consent to participate

Not applicable.

\section{Consent for publication}

All authors have reviewed this work and consent to publication.

\section{Competing interests}

The authors have no competing interests to disclose.

Received: 14 May 2020 Accepted: 2 November 2020

Published online: 12 November 2020

\section{References}

1. Baum Hedlund Aristei Goldman, PC. "Monsanto Hit with $\$ 2$ Billion Verdict Losing Third Roundup Trial." Baum Hedlund Arstei Goldman, PC. Press release, May 13, 2019. Retrieved from https://www.baumhedlundlaw.com/2billion-verdict-against-monsanto/, accessed 15 Nov 2019.

2. Benbrook CM. Trends in glyphosate herbicide use in the United States and globally. Environ Sci Eur. 2016;28(1):3.

3. EPA, Federal Register (Ed.). Glyphosate; pesticide tolerances. Washington, DC: U.S. Environmental Protection Agency; 2013. p. 25396-401.

4. Zhang L, Rana I, Shaffer R, Taioli E, Sheppard L. Exposure to glyphosatebased herbicides and risk for non-Hodgkin lymphoma: a meta-analysis and supporting evidence. Mutat Res. 2019;781:186-206.

5. Pahwa M, Beane Freeman LE, Spinelli JJ, Blair A, McLaughlin JR, Zahm SH, et al. Glyphosate use and associations with non-Hodgkin lymphoma major histological sub-types: findings from the north American pooled project. Scand J Work Environ Health. 2019:45(6):600-9.

6. Gillezeau C, van Gerwen M, Shaffer R, Rana I, Zhang L, Sheppard L, et al. The evidence of human exposure to glyphosate: A Review. Environmental Health. 2019;18(2). https://doi.org/10.1186/s12940-018-0435-5.

7. Wild CP, Kleinjans J. Children and increased susceptibility to environmental carcinogens: evidence or empathy? Cancer Epidemiol Biomarkers and Prev. 2003;12(12):1389-94.

8. Curwin BD, Hein MJ, Sanderson WT, Striley C, Heederik D, Kromhout H, Reynolds SJ, Alavanja MC. Urinary pesticide concentrations among children, mothers and fathers living in farm and non-farm households in lowa. Ann Occup Hyg. 2007:51(1):53-65.

9. Knudsen LE, Hansen PW, Mizrak S, Hansen HK, Morck TA, Nielsen F, Siersma $\checkmark$, Mathiesen L. Biomonitoring of Danish school children and mothers including biomarkers of PBDE and glyphosate. Rev Environ Health. 2017; 32(3):279-90. 
10. Rappaport SM. Assessment of long-term exposures to toxic substances in air. Ann Occup Hyg. 1991;35(1):61-121.

11. Trasande L, Aldana SI, Trachtman H, Kannan K, Morrison D, Christakis DA, et al. Glyphosate exposure and kidney injury biomarkers in infants and young children. Environ Pollut. 2020;256:113334.

12. Sierra-Diaz E, Celias-de la Rosa A, Lozano-Kasten F, et al. Urinary pesticide levels in children and adolescents residing in two agricultural communities in Mexico. Int J Environ Res Public Health. 2019;16(4). https://doi.org/10. 3390/ijerph16040562.

13. Perry M, Mandrioli D, Belpoggi F, Manservisi F, Sanzacchi S, Irwin C. Historical Evidence of Glyphosate Exposure from a US Agricultural Cohort. Environmental Health [letter to the editor]; 2019.

14. Balderrama-Carmona AP, Valenzuela-Rincon M, Zamora-Alvarez LA, AdanBante NP, Leyva-Soto LA, Silva-Beltran NP, Moran-Palacio EP. Herbicide biomonitoring in agricultural workers in Valle Del Mayo, Sonora Mexico. Environ Sci Pollution Res. 2019; https://doi.org/10.1007/s11356-019-07087-6.

15. Wongta A, Swarng N, Tongchai P, Sutan K, Kerdnoi T, Prapamontol T, Hongsibsong $\mathrm{S}$. The pesticide exposure of people living in agricultural community, Northern Thailand. J Toxicology. 2018.

16. World Health Organization. Glyphosate and AMPA in Drinking-water. Retrieved from https://www.who.int/water_sanitation_health/dwq/ chemicals/glyphosateampa290605.pdf?ua=1. 2005.

17. Connolly A, Jones K, Basinas I, Galea K, Kenny L, McGowan P, Coggins M. Exploring the half-life of glyphodate in human urine samples. Int J Hyg Environ Health 2019. 222(2): 205-210.

18. Hines EP, Mendola P, von Ehrenstein OS, Ye X, Calafat AM, Fenton SE. Concentrations of environmental phenols and parabens in milk, urine and serum of lactating North Carolina women. Reprod Toxicol. 2015;54:120-8. https://doi.org/10.1016/j.reprotox.2014.11.006.

19. Centers for Disease Control and Prevention. Data Sources and Data Analysis. National Report on Human Exposure to Environmental Chemicals. Retrieved from https://www.cdc.gov/exposurereport/data_sources_analysis.html.

20. Sattler B, Davis DBA. Nurses' role in children's environmental health protection. Pediatr Nurs. 2008;34(4):329-39.

21. Landrigan PJ. Children as a vulnerable population. Int J Occup Med Environ Health. 2004;17(1):175-7.

22. Jayasumana C, Gunatilake S, Siribaddana S. Simultaneous exposure to multiple heavy metals and glyphosate may contribute to Sri Lankan agricultural nephropathy. BMC Nephrol. 2015;16:103.

23. Mills PJ, Kania-Korwel I, Fagan J. Excretion of the herbicide glyphosate in older adults between 1993-2016. JAMA. 2017:318(16):1601-11.

24. Office of Chemical Safety And Pollution Prevention: Glyphosate. Dietary Exposure Analysis in Support of Registration Review. Washington, DC: United States Environmental Protection Agency; 2017. p. 1-20.

25. Silva V, Montanarella L, Jones A, Fernandez-Ugalde O, Mol HGJ, Ritsema CJ, Geissen V. Distribution of glyphosate and aminomethylphosphonic acid (AMPA) in agricultural topsoils of the European Union. Sci Total Environ. 2018:621:1352-9.

26. Curwin BD, Hein MJ, Sanderson WT, Nishioka MG, Reynolds SJ, Ward EM Alavanja MC. Pesticide contamination inside farm and nonfarm homes. J Occup Environ Hyg. 2005;2(7):357-67.

\section{Publisher's Note}

Springer Nature remains neutral with regard to jurisdictional claims in published maps and institutional affiliations.

Ready to submit your research? Choose BMC and benefit from:

- fast, convenient online submission

- thorough peer review by experienced researchers in your field

- rapid publication on acceptance

- support for research data, including large and complex data types

- gold Open Access which fosters wider collaboration and increased citations

- maximum visibility for your research: over $100 \mathrm{M}$ website views per year

At $\mathrm{BMC}$, research is always in progress.

Learn more biomedcentral.com/submissions 